\title{
Protocirrineris (Polychaeta:Cirratulidae) in South Africa and description of two new species
}

\author{
Rodolfo Elías ${ }^{1}$, María Andrea Saracho-Bottero ${ }^{1}$, \& Carol Anne Simon ${ }^{2}$ \\ 1. Universidad Nacional de Mar del Plata - Instituto de Investigaciones Marinas y Costeras, CONICET-UNMdP, \\ Argentina, roelias@mdp.edu.ar, asaracho@mdp.edu.ar \\ 2. Department of Botany and Zoology. Stellenbosch University, South Africa, csimon@sun.ac.za
}

Received 22-X-2018. C Corrected 22-II-2019. Accepted 30-VI-2019.

\begin{abstract}
Introduction: The knowledge of polychaetes in the subtropical region of Africa benefited from the activity of J. Day. However, 50 years after the publication of his Monograph of the Polychaeta of southern Africa, it is necessary to reconsider the identity of the Cirratulidae due to changes in the diagnostic characters and new approaches to the taxonomy of the group to corroborate the status of cosmopolitan species in this region. Objective: We hypothesize that biodiversity of multitentacular Cirratulidae polychaetes has been significantly underestimated in southern Africa. Methods: The present work analyzes material deposited in the Iziko museum, as well as recently collected specimens, using scanning electron microscope to identify them. Results: The material corresponds to two new species belonging to the genus Protocirrineris. Protocirrineris strandloperarum sp. nov. is characterized by having the tentacular filaments between the chaetigers 5 to 10-12 and the first pair of branchiae from chaetiger 7, and P. magalhaesi sp. nov. is characterized by having tentacular filaments between chaetigers 4-8 and the first pair of branchiae from chaetigers 2 or 3 . Descriptions of these species, with light and scanning electron microscope images, are given. Schematic drawings of the two new species are shown comparatively with diagnostic characters. Conclusions: The use of new techniques enables discovery of new taxonomic characters and two new species of the genus. The diversity of Cirratulidae polychaetes is underestimated also in the subtropical and tropical regions of Africa.
\end{abstract}

Key words: Taxonomy; Cirratulidae; Protocirrineris, new species, cosmopolitan distribution, misidentifications.

Elías, R., Saracho-Bottero, M.A., \& Simon, C.A. (2019). Protocirrineris (Polychaeta:Cirratulidae) in South Africa and description of two new species. Revista de Biología Tropical, 67(S5) Suplemento, S70-S80.

Historically, many invertebrate species have been reported over erroneously broad geographical ranges because the finer distinctions between species were overlooked. In polychaetes, poor species descriptions and illustrations exacerbated the problem by leading to misidentifications, and European names were consequently applied to taxa globally (Hutchings \& Kupriyanova, 2018). In particular, the true diversity of the family Cirratulidae is currently unknown due to a large number of undescribed species and "cosmopolitan" names being erroneously applied to local species (Tewary, 2015; Saracho-Bottero, Magalhães \& Elías, 2017).

Among the bitentaculate cirratulids, there are several examples of misidentifications. Blake (2015) demonstrated that Chaetozone setosa Malmgren, 1867, originally described from Norway but since "identified" globally, is actually limited to the Arctic; reports from other places represent misidentifications 
(Tewary, 2015). Another example could be the widely distributed, near cosmopolitan Caulleriella alata (Southern, 1914), that in the Southwestern Atlantic was recently described as a new species (Elías \& Rivero, 2009). Among the multitentaculate cirratulids, Cirratulus cirratus (O.F. Müller, 1776) also seems to have a cosmopolitan distribution, but it is probably another example of global misidentification. Thus, we need to review the classification of the family worldwide and since the Southern Hemisphere in particular has been poorly sampled, it is expected that newly collected material will lead to the description of several new species.

The knowledge of polychaetes in South Africa and adjacent areas benefitted from the activity of the great polychaetologist John Day, who published a series of scientific contributions from coastal areas of Southern Africa, culminating in the publication of the Monograph of Polychaeta of southern Africa (Day, 1967). However, many of the species reported in the monograph are not endemic to the region and have a 'cosmopolitan' distribution. Given that many of these apparently cosmopolitan species may in fact represent complexes of morphologically similar or identical species (e.g., Hutchings \& Kupriyanova, 2018), we hypothesize that polychaete biodiversity has been significantly underestimated in southern Africa. Furthermore, the characters and tools used to identify and classify species have changed over time. The Scanning Electronic Microscope (SEM) represents a significant development in our understanding of external morphology. Additionally, diagnostic characters of some families have been revised, and among cirratulids, the redescription and restatement of some genera necessitated several changes to old classifications. It is therefore important that the cirratulids from South Africa are revised, since they have not been subjected to any taxonomic revisions for 50 years, while only one paper devoted to cirratuliforms in the region has been published in this time (Weidhase, Bleidorn, \& Simon, 2016). One taxon in particular needs attention; the species Cirratulus chrysoderma
Claparède, 1868 cited by Day (1967: 511) has been transferred to Protocirrineris Czerniavsky, 1881 (reinstated by Petersen, 1991), since they lack acicular spines and their tentacular filaments are arranged in rows, which are diagnostic characteristics of the genus Protocirrineris according to Blake (1996). Furthermore, the European name "chrysoderma" must be revisited, because it is unlikely that a Mediterranean species could be naturally present in South African waters. The revision of Day's material deposited in the Iziko Museum of Cape Town, and new material recently collected from Lamberts Bay and earlier unpublished studies investigating polychaete diversity provide the opportunity to study the Protocirrineris present in South Africa.

The present work describes the presence of Protocirrineris in South African waters for the first time. Two new species are described and compared to other similar species.

\section{MATERIAL AND METHODS}

The revision of Protocirrineris includes material deposited by J. Day in the Natural History Museum of South Africa, the Iziko Museum in Cape Town. Specimens of the new Protocirrineris were also provided by Dr. Carol A. Simon from her personal collection of polychaetes from abalones collected from the farm in Haga Haga (34⒋' S - 28 $14^{\circ}$ E) in 2007, and also collected by M.A. SarachoBottero \& R. Elías in 2016 in Lamberts Bay $\left(32^{\circ} 05^{\prime} \mathrm{S}-18^{\circ} 18^{\prime} \mathrm{E}\right)$. These locations span two ecoregions; Haga Haga lies on the southeast coast, thus falling within the warm temperate Agulhas Ecoregion (mean annual temperatures range from 14 to $16^{\circ} \mathrm{C}$ ), summer temperatures can exceed $18{ }^{\circ} \mathrm{C}$, while Lamberts Bay falls within the Southern Benguela Ecoregion (mean annual temperatures range from 12 to $14{ }^{\circ} \mathrm{C}$ ) (Sink et al., 2012; Smit et al., 2013).

The specimens were examined with optical equipment of the Stellenbosch University of South Africa (Stereomicroscope Leica MZ75, Compound Microscope Leica DM 1000, with Leica EC3 camera attachment). 
Material donated to this study was processed by a scanning electron microscope (SEM) JEOL, JSM-6460 LV in the Mar del Plata National University. The material for SEM was prepared performing dehydration in ethyl alcohol (70, 80, 90, 95 and $100 \%)$. Samples were dried in HMDS (hexamethyldisilazane), mounted on aluminum studs and sputter coated with Gold Palladium.

Type material of Protocirrineris and voucher specimens of the two new species are deposited in the Iziko Museum. Zoobank link: LSIDurn:1sid:zoobank.org:pub:9C9F48B0C2B4-4F70-B70F-F52056AC7721

\section{SYSTEMATIC ACCOUNT}

Family Cirratulidae Ryckholt, 1851

Genus Protocirrineris Czerniavsky, 1881

Type Species: Cirratulus tenuisetis Grube, 1860, designated by Hartman (1959)

Diagnosis (after Blake, 1996; Blake \& Magalhães, 2017): Prostomium bluntly conical to wedge-shaped, with or without eyes. Body nearly round in cross section, with distinct segments. Grooved tentacular filaments few, arising singly or in paired groups on several anterior chaetigers following chaetiger 1 ; individual tentacular filaments often arranged in longitudinal rows. Branchiae occurring singly, usually first present from segments with tentacular filaments, sometimes on more anterior chaetigers. Chaetae all capillaries.

Remarks: Day (1967) identified several multitentaculate Cirratulidae, and one of them was identified as Cirratulus chrysoderma. This species was transferred to the genus Protocirrineris because it lacks acicular spines and has tentacular filaments arranged in rows rather than in groups. Furthermore, the South African record clearly does not belong to "chrysoderma" since the species described by Claparède (1868) has permanent pigmentation of the skin due to gold deposit, the tentacular filaments seem to be between chaetigers 4 and 7 (although the original description is not clear about its segmental distribution), and branchiae start on chaetiger 4 but become lateral from chaetiger 10 , which are not characters of any of the South African species.

\section{Protocirrineris strandloperarum sp. nov. Elías, Simon \& Saracho-Bottero}

(Fig. 1A-F; 3A; 4A-C)

Material examined: Iziko Museum of Cape Town: The whole batch consists in seven complete specimens and two anterior regions (Collected and identified by J.H. Day as Orthocirratulus chrysoderma. St. James shore Station, UCT ecological survey, batch $n^{\circ} 20654$ ).

Additional material: Two complete specimens and two anterior regions for SEM (batch 20654).

Material collected and identified as Cirratulids by Dr. Carol Anne Simon, from surface of farmed Haliotis midae Linnaeus, 1758, Haga Haga farm, 26 April 2007, South Africa. Eight specimens analyzed with SEM; One complete specimen as Holotype.

Material collected in South Africa intertidal, among coralline algae in Lamberts Bay, Saracho-Bottero and Elías col., October $19^{\text {th }}$, 2016), a single specimen analyzed by SEM.

Description: Holotype complete, $7 \mathrm{~mm}$ long, $0.5 \mathrm{~mm}$ wide for about 130 chaetigers (SAMC A089060). Paratypes, five complete specimens (batch 20654) ranging 30-55 mm long, 1-1.45 mm wide for 80-143 chaetigers (SAMC A089061).

Body rounded dorsally and ventrally flattened; wider at thoracic chaetigers and tapering posteriorly, not expanded; pygidium with 3-5 lobes, anus terminal (Fig. 1A; 3A). Body color in alcohol brown or pale brown. Additional incomplete specimen white in color (20172), possibly belonging to this species.

Prostomium short, conical, with a pair of oblique postero-lateral nuchal organs (Fig. $1 \mathrm{C})$; peristomium with three sub-equal annulations and several secondary annulations laterally, dorsum smooth with crest (Fig. 1A, B), although some paratypes lack crest. First three chaetigers wide, as long as peristomium, 

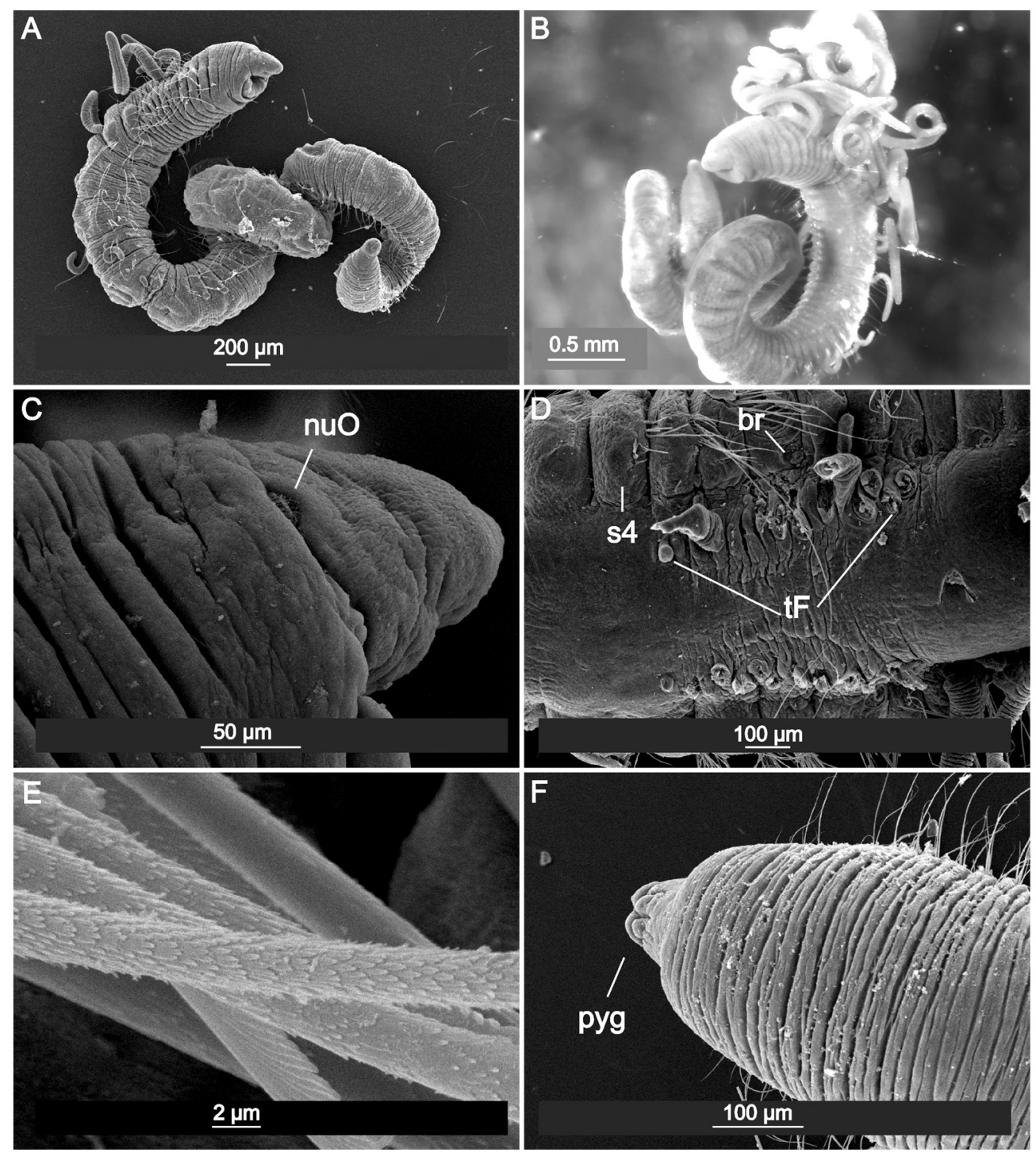

Fig. 1. Protocirrineris strandloperarum sp. nov. A: SEM of general view; B: Photomicrograph of complete holotype; C: SEM of pre-chaetigerous region and anterior most segment, nuO: nuchal organ; D: SEM of detail of anterior region showing insertion of tentacular filaments in rows between chaetigers 5 to 10, and first branchiae in chaetiger 7; E: SEM of fimbriate capillaries; F: SEM of posterior region and pygidium (pyg).

following chaetigers narrow and crowded forming discreet lateral shoulders (Fig. 1A, B). Tentacular filaments (two-three pairs in each segment) starting on chaetiger 5 and extending to the 10th (sometimes to chaetiger 12) (Fig. 1B; D). Branchial filaments first arising from posterior region of chaetiger 7 , one pair per segment; more abundant on anterior region and absent on posterior region. Chaetae all fimbriated capillaries, some saber-like with a serrated edge and other capillaries rounded in cross section with scales (Fig.1E); 8-10 on each anterior noto- and neuropodia, reducing to 4-6 posteriorly. Posterior region not expanded; pygidium conical, with three to five lobes; anus terminal (Fig. 4A, B, C). 
Methyl green staining pattern (MGSP): No distinctive staining pattern. Whole worm stained with a light green.

Habitat: Several specimens were collected in the intertidal region of Lamberts Bay during 2016, among coralline algae. Previously, samples were collected from the surface of Haliotis midae from an on-shore culture facility. The material deposited in the Iziko museum (batch 20654) was collected by J.H. Day from Cape (False Bay).

Distribution: Previously only collected from the Western Cape Province, from Buffels River on the west coast to Still Bay on the south coast. The record from Haga Haga is the first report from the Eastern Cape Province.

Etymology: The species is dedicated to the people of South Africa. 'Strandloper' is the Afrikaans and Dutch word that originally referred to the indigenous shore dwelling, hunter gathering, people who occurred on the western coast of South Africa. More recently it has been informally adopted by 'beach bums', people attracted to the beach lifestyle.

Remarks: Protocirrineris strandloperarum sp. nov., is similar in shape to $P$. angelicollatio from the Southwestern Atlantic (Elías \& Rivero, 2009) but segmental origin of tentacular filaments differ: in chaetigers 4-7 in P. angelicollatio but in chaetigers 5-10 (or 12) in $P$. strandloperarum sp. nov. Although branchiae start from chaetigers 7 in both species, the first pair of branchiae start among segments with tentacular filaments in P. strandloperarum $\mathrm{sp}$. nov. but in the last chaetiger bearing tentacular filaments in P. angelicolliatio. The same comparison could be made with the similar $P$. purgamentorum from Mediterranean Sea (Lezzi et al., 2016). P. strandloperarum sp. nov., $P$. nuchalis and $P$. indicus are characterized by having more chaetigers bearing tentacular filaments (5-10/12, 7-17 and 7-11, respectively), compared to P. chrysoderma (4-7?); P. purgamentorum and $P$. angelicolliatio (4-7); and $P$. socialis (3-5) and P. mascaratus (1-2 or 2-3). P. indicus (Day, 1973) has only capillary chaetae and tentacular filaments in rows and first branchiae starting in chaetiger 7 and extending to chaetigers 11 , thus resembling $P$. strandloperarum sp. nov. These species differ in that $P$. indicus lacks parapodial shoulders and has a considerably long peristomium that is as long as six anterior chaetigers. The shape is also similar to P. mascaratus (Magalhães \& Bailey-Brock, 2013), but in this species, tentacular filaments are not in rows as in $P$. strandloperarum sp. nov. The pygidium of $P$. strandloperarum sp. nov. is characterized by the presence of three to five lobes.

\section{Protocirrineris magalhaesi sp. nov. Elías \& Saracho-Bottero (Fig. 2A-F; 3B; 4D-F)}

Material examined: Iziko Museum of Cape Town: The whole batch consists of four complete specimens (Collected and identified by J.H. Day as Cirriformia tentaculata, at South Africa, Alexander Bay, batch $n^{\circ}$ 20077).

Seven complete specimens (South Africa, Lamberts Bay, Saracho-Bottero and Elías col., October $19^{\text {th }}, 2016$ among coralline algae).

Additional material: One complete specimen and two anterior fragments analyzed by SEM (batch $n^{\circ}$ 20077).

Seven complete specimens (South Africa, Lambert Bay, Saracho-Bottero and Elías col., October $19^{\text {th }}, 2016$ among coralline algae).

Description: Holotype $13 \mathrm{~mm}$ long, 0.7 $\mathrm{mm}$ wide for about 160 chaetigers (SAMC A089062). Paratypes four complete specimens ranging from $12-14 \mathrm{~mm}$ long, $0.5-0.7 \mathrm{~mm}$ wide for 150-180 chaetigers (SAMC A089063).

Body rounded dorsally and ventrally flattened; thoracic chaetigers wider with shoulders; posterior segments inflated; Pygidium a simple lobe, anus dorsal (Fig. 2A). Body color in alcohol brown.

Prostomium very short, with a pair of oblique postero-lateral nuchal organs; peristomium smooth composed of a single annulus as long as 2-3 anterior chaetigers (Fig. 2A). First 8-9 chaetigers slightly wider in comparison to narrow and crowded following chaetigers. Tentacular filaments 2-3 pairs on each side; first pair on posterior region of chaetiger 4 

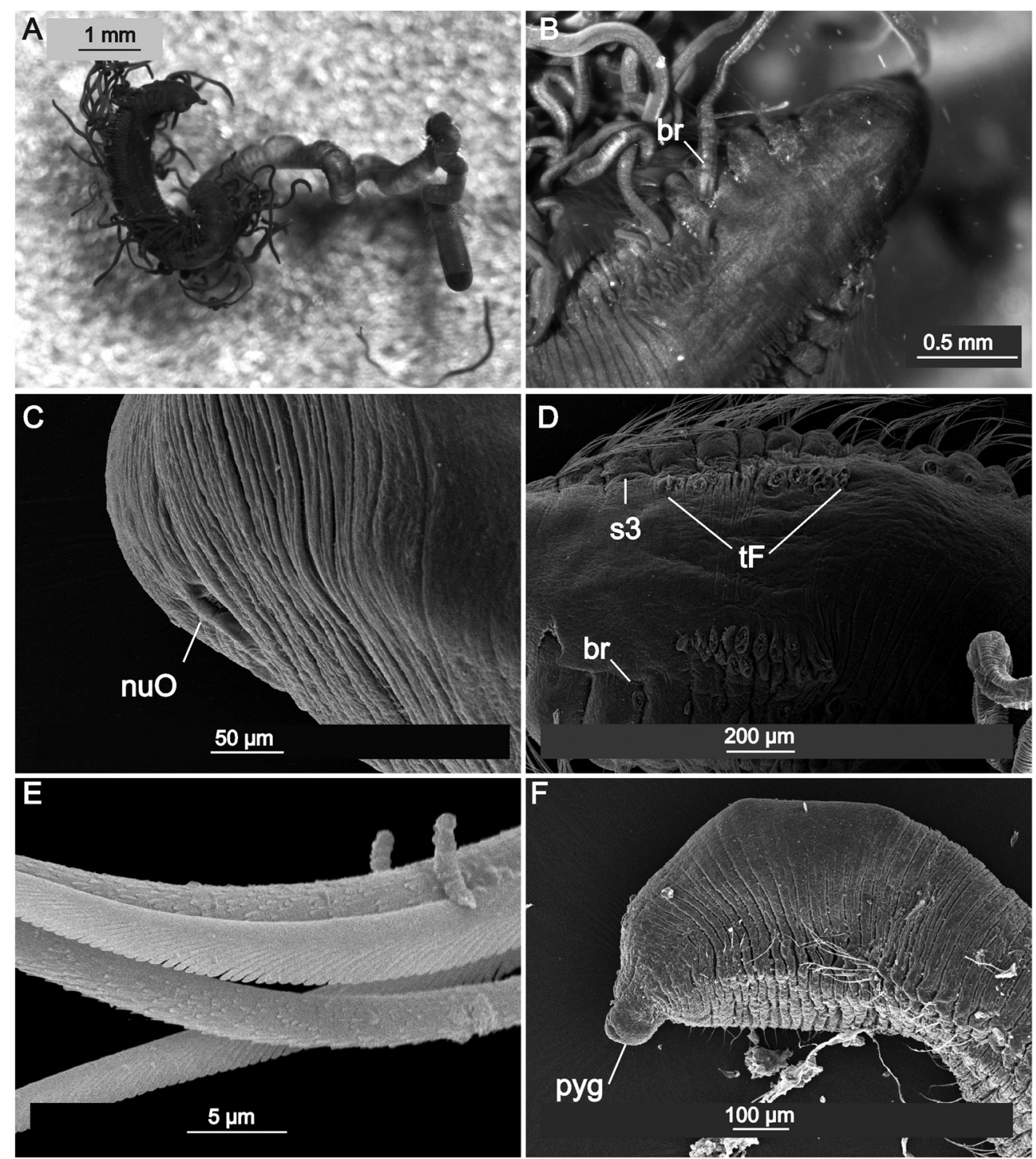

Fig. 2. Protocirrineris magalhaesi sp. nov. A: Photomicrograph of complete holotype; B: Photomicrograph of detail of prechaetiger region showing first branchiae in chaetiger 3; C: SEM of pre-chaetiger region and anterior most segment, nuO: nuchal organ; D: SEM showing anterior region in dorsal view with tentacular filaments in rows between chaetigers 4 to 8 , and first branchiae in chaetiger 3; E: SEM of fimbriate capillaries; F: SEM of pygidium.

extending to chaetiger 8 (sometimes 9) (Figs. 2C; 3B). Branchial filaments first arising from chaetiger 2 or 3 (Fig. 2B; 3B), one pair per chaetiger, more abundant on anterior region and absent on posterior region. Parapodia well developed in thoracic region forming lateral shoulders (Fig. 2A, B), becoming more ventral than lateral in mid-body and indistinct in posterior chaetigers. Chaetae all fimbriated capillaries, some saber-like with a serrated edge and others rounded in cross section with scales (Fig. 2E); 8-10 on each anterior noto- and neuropodium, reducing to 4-6 posteriorly (Fig. 4D, E, F). Posterior region usually dorsally inflated, 

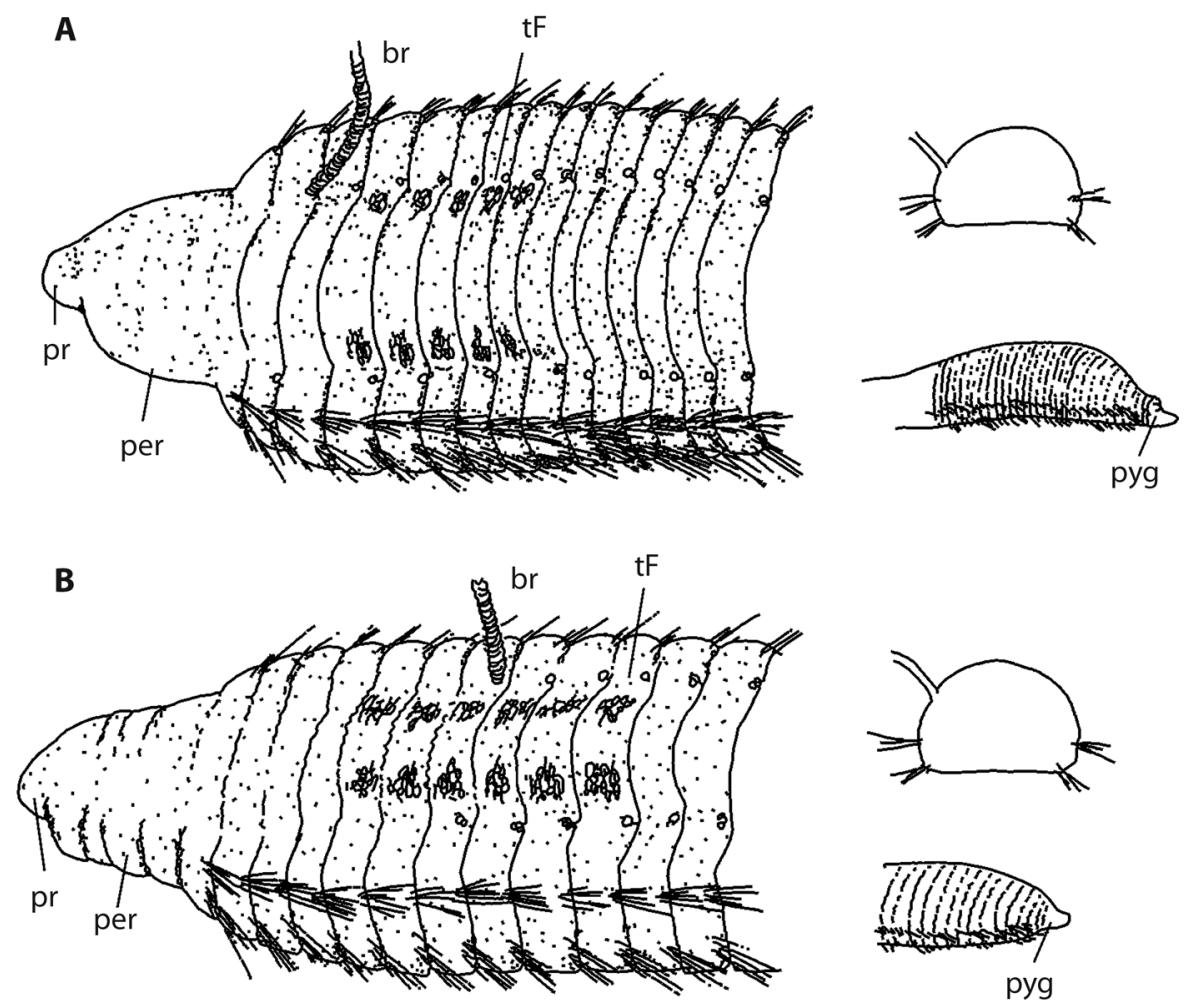

Fig. 3. Schematic drawings of A: Protocirrineris strandloperarum sp. nov. and B: P. magalhaesI sp. nov. showing comparatively the diagnostic characters.
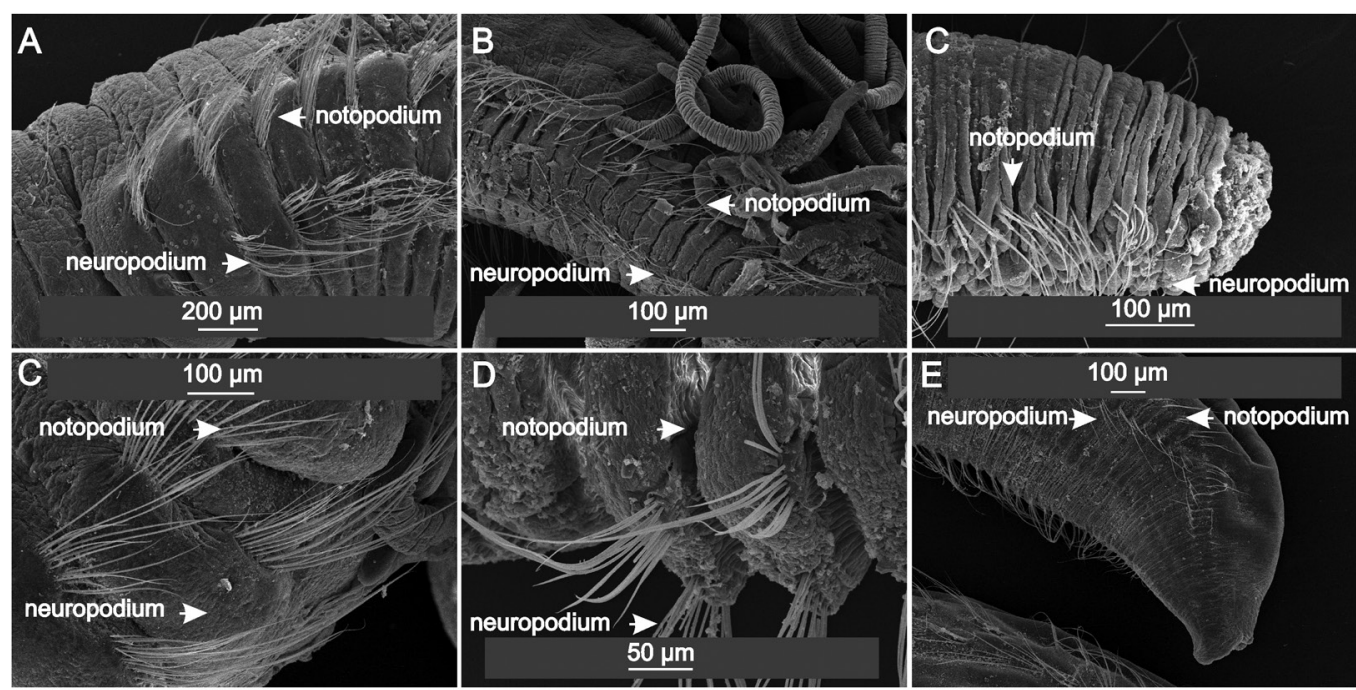

Fig. 4. SEM of A-C: Protocirrineris strandloperarum sp. nov. and D-F: P. magalhaesi sp. nov. showing comparatively, A and $\mathbf{D}$ the capillaries of anterior segments; $\mathbf{B}$ and $\mathbf{E}$ the capillaries of middle segments; $\mathbf{C}$ and $\mathbf{F}$ the capillaries of posterior segments. 
ventrally flat; pygidium a simple conical lobe, anus opening dorsally (Fig. 2F).

Methyl green staining pattern (MGSP): No distinctive staining pattern.

Habitat: In Lamberts Bay, the material was collected among low intertidal coralline red algae.

Distribution: To date, this species was only found at Lamberts Bay on the west coast of the Western Cape Province and Alexander Bay in the Northern Cape Province.

Etymology: The species is dedicated to Wagner Magalhães, for his contribution to Cirratulidae.

Remarks: The origin of both tentacular filaments and branchiae are not only diagnostic characters for the genus but also for the species. Protocirrineris magalhaesi sp. nov. has tentacular filaments from chaetiger 4 extending to chaetiger 8-9 and first pair of branchiae arising from chaetiger 2 or 3 , while in P. strandloperarum sp. nov., the first pair of branchiae start among segments with tentacular filaments (starting from chaetiger 5 to 10 or 12). Additional characters, such as the peristomium being dorsally smooth with lateral annulations and having a posterior region dorsally inflated distinguishes $P$. magalhaesi from $P$. strandloperarum sp. nov. which has a quadrangular peristomium and posterior region not dorsally inflated. The pygidium is conical with a terminal anus in $P$. magalhaesi sp. nov., but in $P$. stranloperarum sp. nov. it has 3-5 lobes and a dorsal anus, a character unique to this species (Fig. 3A, B). The chaetae are all fimbriated capillaries that are different from other species of Protocirrineris. Some capillaries are curved and flattened laterally, shaped like a saber and with one side with long teeth, being born from the midline of the capillary and forming a serrated edge with blunt teeth, while other capillaries are round in cross-section with small scales or teeth attached to the surface, spaced but regular (Fig. 2E). The saber chaetes are also present in $P$. strandloperarum sp. nov., but capillaries with rounded cross-section have much more scales or long teeth attached to the surface (Fig. 1E).

\section{DISCUSSION}

Claparède (1868) described the species Cirratulus chrysoderma from Naples in the Mediterranean Sea. This species is now known as Protocirrineris chrysoderma and is considered valid although descriptions of distinctive morphological characters are still lacking. The distribution of this nominal species is wide in the Mediterranean, and also in the Atlantic and Pacific Oceans (Day, 1967). However, Petersen (1991) considered P. chrysoderma a complex of species. The results of our study provide further evidence to support Petersen (1991), as the South African P. chrysoderma had clearly been misidentified; not only was it identified as a Cirratulus, but Day (1967) illustrates a morphotype with tentacular filaments in rows along chaetigers 4-7. To further add to the confusion, the species described by Day (1967) differs from specimens examined in this study, including some that had been identified by Day as C. chrysoderma. Day (1973) also described a Protocirrineris indicus (as Cirratulus) from south of Bombay (India) characterized by having the first branchiae from chaetiger 7 together with tentacular filaments that extend up to chaetiger 11 .

The twelve described species of Protocirrineris may be distinguished by the segmental origin, extent and number of feeding tentacles as well as the first appearance of branchiae (Table 1 in Elías, Saracho-Bottero \& Magalhães (2019), in this volume). The origin of branchiae, also an important character, is usually variable, occurring generally in anterior chaetigers, but in some species are posterior (like in $P$. angelicolliatio and P. strandloperarum sp. nov.). The branchiae arise from the posterior part of the notopodium and the insertion is often hidden, and branchiae are sometimes difficult to see without the aid of SEM images. Recently, some specimens of $P$. angelicolliatio were found to have branchiae first appearing in anterior chaetigers (chaetiger 3) while in all described specimens the first branchiae were in chaetigers 7 (Saracho-Bottero, personal observation). This calls into question 
the importance of such a variable character as a diagnostic feature in this genus. Possibly the origin of the first branquiae is more anterior, but by easily detaching the insertion mark cannot be observed with traditional methods (microscope or stereomicroscope).

The ultrastructure of capillary fibrils might also be a valuable diagnostic character (Magalhães \& Bailey-Brock, 2013). Although this character has only been shown for the four species for which scanning electron micrographs are available (Protocirrineris strandloperarum sp. nov., P. magalhaesi sp. nov., and P. mascaratus and $P$. angellicolatio), the fibrils appear to be distinct with respect to width, shape, and number along the capillary chaetal blade for each species. The usefulness of capillary fibrils to cirratulid taxonomy has previously been discussed for the bitentaculate genus Aphelochaeta (Doner \& Blake, 2009) but a unifying terminology is still lacking (Magalhães, 2015). Additionally, the two new species described herein had some chaetae that were rounded in cross section and finely denticulated, while some had a flat blade that was dentate on one side. The species Protocirrineris purgamentorum from the Mediterranean Sea (Lezzi et al., 2016) have some capillary chaetae with a saber-like tip, with denticulation in one edge seen at light microscope. The shape, fibrils and denticulation of chaetae might be useful characters to use in future.

Day (1967) reported 22 species of cirratulids for southern Africa, of which 12 have type localities outside of the region. Awad, Griffiths, \& Turpie (2002) ascribed the low proportion of indigenous species in South Africa to the fact that this taxon has been well-sampled globally, but it is more likely that many of these non-indigenous species had actually been misidentified (see also Lewis \& Karageorgopolous, 2008; Clarke, Paterson, Florence, \& Gibbons, 2010; Simon, Sato-Okoshi, \& Abe, 2019; Simon, Williams, \& Henninger, 2019; Kara, Macdonald, \& Simon, 2018), and that diversity of indigenous species has been greatly underestimated. It is therefore not surprising that the apparently cosmopolitan $P$. chrysoderma is actually two new indigenous species. Similarly, it is not surprising that the two new species of Protocirrineris were described from a single locality (Lamberts Bay), given that Simon, San Martín, \& Robinson (2014) previously described two new species of the genus Syllis from a single location. This study therefore supports Tewary (2015) who predicted that the full extent of the diversity of cirratulids is still to be discovered. New species will undoubtedly be detected and the geographic distribution of the species described in this study can be defined as more studies are conducted in the subtropical and tropical regions of Africa.

Ethical statement: authors declare that they all agree with this publication and made significant contributions; that there is no conflict of interest of any kind; and that we followed all pertinent ethical and legal procedures and requirements. All financial sources are fully and clearly stated in the acknowledgements section. A signed document has been filed in the journal archives.

\section{AKNOWLEDGEMENTS}

We thank loan BID (Inter-American Bank of Development), PICT $\mathrm{n}^{\circ} 1511$ to Rodolfo Elías. We thank to Zenobia Davids for the accommodation in Crozierhof of the University of Stellenbosch. We especially thank Elizabeth Hoenson the curatorial assistant and Wayne Florence, curator of the marine invertebrate collection, of the Iziko Museums of South Africa for the loan of the deposited material. Jyothi Kara for all her help in the field and the trip to Iziko museum. We must also thank her for transporting of type material from Argentina to South Africa. SEM images were obtained by Mónica Oppedisano from the Laboratorio de Microscopía Electrónica of Facultad de Ciencias Exactas y Naturales of the Universidad Nacional de Mar del Plata. Nestor Cazzaniga (UNS) helped in nomenclature. The drawings were made by R. E. Figures composition by M.A.S.B. Wagner Magalhães and two anonymous reviewers improved the manuscript. 


\section{RESUMEN}

Protocirrineris (Cirratulidae: Polychaeta) en Sudáfrica y la descripción de dos nuevas especies. Introducción: El conocimiento de los poliquetos de la región subtropical de África fue logrado gracias a John Day. Sin embargo, 50 años después es necesario reconsiderar la identidad de los Cirratulidae, debido a los cambios en los caracteres diagnósticos y a las nuevas herramientas de análisis. Objetivo: Nuestra hipótesis es que la biodiversidad de los poliquetos cirratulidos multitentaculares ha sido subestimada significativamente en el sur de África. Métodos: El trabajo actual analiza muestras tomadas recientemente y material depositado en el museo de Iziko con microscopia electrónica de barrido para su identificación. Resultados: El material corresponde a dos especies nuevas, Protocirrineris strandloperarum sp. nov. y Protocirrineris magalhaesi sp. nov. Una imagen esquemática con los caracteres diagnósticos es dada para las especies descriptas en este trabajo. Conclusiones: el uso de nuevas técnicas permitió descubrir nuevos caracteres diagnósticos y dos nuevas especies del género. La diversidad de Cirratulidae también está subestimada en la región subtropical y tropical de África.

Palabras clave: Taxonomía; Cirratulidae; Protocirrineris, África del Sur, Distribución cosmopolita, identificaciones erróneas.

\section{REFERENCES}

Awad, A., Griffiths, C. L., \& Turpie, J. K. (2002). Distribution of South African marine benthic invertebrates applied to the selection of priority conservation areas. Diversity and Distributions, 8, 129-145.

Blake, J. A. (1996). Family Cirratulidae Ryckholdt, 1851. Including a revision of the genera and species from the Eastern North Pacific. In J. A. Blake, B. Hilbig \& P. H. Scott (Eds.). Taxonomic Atlas of the Benthic Fauna of the Santa Maria Basin and Western Santa Barbara Channel, Volume 6. The Annelida Part 3. Polychaeta: Orbiniidae to Cossuridae (pp. 263384). Santa Barbara, California, USA: Santa Barbara Museum of Natural History.

Blake, J. A. (2015). New species of Chaetozone and Tharyx (Polychaeta: Cirratulidae) from the Alaskan and Canadian Arctic and the Northeastern Pacific, including a description of the lectotype of Chaetozone setosa Malmgren from Spitsbergen in the Norwegian Arctic. Zootaxa, 3919(3), 501-552.

Blake, J. A., \& Magalhães, W. F. (2017). Family Cirratulidae Ryckholt, 1851. In W. Westheide \& G. Purschke (Eds.). Handbook of Zoology, a Natural History of the Phyla of the Animal Kingdom (pp. 1-56). Berlin, Germany: de Gruyter.
Claparède, E. (1868). Les Annélides Chétopodes du Golfe de Naples. Memoires de la Société de physique et d'histoire naturelle de Genève 20(2), 365-542.

Clarke, D. T., Paterson, G., Florence, W. K., \& Gibbons, M. J. (2010). A new species of Magelona (Polychaeta: Magelonidae) from southern Namibia. African Natural History, 6, 77-82.

Czerniavsky, V. (1881). Materialia Ad Zoographiam Ponticam Comparatam. Fasciculum III. Vermes. Bulletin de la Société Impériale des Naturalistes de Moscou, 55(4), 213-344.

Day, J. H. (1967). A monograph on the Polychaeta of Southern Africa. Part 1 Errantia and Part 2 Sedentaria. London, UK: British Museum of Natural History Publications.

Day, J. H. (1973). Polychaetes collected by U.D. Gaikwat at Ratnagiri, South of Bombay. Zoological Journal of the Linnean Society, 52, 337-361.

Doner, S. A., \& Blake, J. A. (2009). Two new species of Aphelochaeta (Polychaeta: Cirratulidae) from deep water off northern California. Zoosymposia 2, 127-137.

Elías, R., \& Rivero, M. S. (2009). Two new species of Cirratulidae (Polychaeta) from Argentine Sea (SW Atlantic). Zoosymposia 2, 139-148.

Elías, R., Saracho-Bottero, M. A., \& Magalhães, W. F. (2019). Two new species of Protocirrineris (Polychaeta: Cirratulidae) from Brazil. Revista de Biología Tropical, X(Suppl. X), S000-S000.

Grube, A. E. (1860). Beschreibung neuer oder wenig bekannter Anneliden. Beitrag: Zahlreiche Gattungen. Archiv für Naturgeschichte, Berlin, 26: 71-118.

Hartman, O. (1959). Catalogue of the Polychaetous Annelids of the World. Parts 1 and 2. Allan Hancock Foundation Occasional Paper, 23, 1-628.

Hutchings, P., \& Kupriyanova, E. (2018). Cosmopolitan polychaetes - fact or fiction? Personal and historical perspectives. Invertebrate Systematics, 32, 1-9.

Kara, J., Macdonald, A. H. H., \& Simon, C. A. (2018). Integrative taxonomic methods reveal an incorrect synonymisation of the South African Pseudonereis podocirra (Schmarda) as the widespread Pseudonereis variegata (Grube) from Chile. Invertebrate Systematics, 32(6), 1282-1297.

Lewis, C., \& Karageorgopoulos, P. (2008). A new species of Marphysa (Eunicidae) from the western Cape of South Africa. Journal of the Marine Biological Association of the United Kingdom, 88(2), 277-287.

Lezzi, M., Çinar, M. E., \& Giangrande, A. (2016). Two new species of Cirratulidae (Annelida: Polychaeta) 
from the southern coast of Italy. Marine Biodiversity, 46(3), 681-686.

Linnaeus, C. (1758). Systema Naturae per regna tria naturae, secundum classes, ordines, genera, species, cum characteribus, differentiis, synonymis, locis $(10$ ed. Vol. II). Stockholm, Sweden: Laurentius Salvius.

Magalhães, W. F. (2015). Reef and shore Polychaetes of Hawaii and the western Pacific Islands (Doctoral thesis). Hawaii, USA: University of Hawaii.

Magalhães, W. F., \& Bailey-Brock, J. H. (2013). A new species of Protocirrineris (Polychaeta: Cirratulidae) from Hawaii including a redescription of the New Zealand Protocirrineris nuchalis. New Zealand Journal of Zoology, 40(3), 196-204.

Malmgren, A. J. (1867). Annulata Polychaeta Spetsbergiae, Groenlandiae, Islandiae et Scandinaviae hactenus cognita. Öfversigt af Kongliga Vetenskaps-Akademien Förhandlingar, 24, 127-235.

Müller, O. F. (1776). Zoologicae Danicae Prodromus, seu Animalium Daniae et Norvegiae indigenarum characteres, nomina et synonyma imprimis popularium. Descriptiones et Historia. Volume 1, i-xxxii, 1-282, plates published in 1777 .

Petersen, M. E. (1991). A review of asexual reproduction in the Cirratulidae (Annelida: Polychaeta), with redescription of Cirratulus gayheadius (Hartman, 1965), new combination, and emendation or reinstatement of some cirratulid genera. Bulletin of Marine Science, 48, 592 .

Saracho-Bottero, M. A., Magalhães, W., \& Elías, R. (2017). Cirratulidae (Polychaeta) from austral regions: Cirratulus species from Argentina, with the description of new species. Journal of the Marine Biological Association of the United Kingdom, 97, 889-896.
Simon, C. A., San Martín, G., \& Robinson, G. (2014). Two new species of Syllis (Polychaeta: Syllidae) from South Africa, one of them viviparous, with remarks on larval development and vivipary. Journal of the Marine Biological Association of the United Kingdom, 94(4), 729-746.

Simon, C. A., Sato-Okoshi, W., \& Abe, H. (2019). Hidden diversity within the cosmopolitan species, Pseudopolydora antennata (Spionidae: Annelida) Marine Biodiversity, 49, 25-42.

Simon, C. A., Williams, L. G., \& Henninger, T. (2019). A new species of Rhynchospio (Annelida: Spionidae) in South Africa. Marine Biodiversity, 49, 663-672.

Sink, K., Holness S., Harris, L., Majiedt, P., Atkinson, L., Robinson, T., ... Wolf, T. (2012). National Biodiversity Assessment 2011: Technical Report. Volume 4: Marine and Coastal Component. Pretoria, South Africa: South African National Biodiversity Institute.

Smit, A. J., Roberts, M., Anderson, R. J., Dufois, F., Dudley, S. F. J., Bomman, T. G., ... Bolton, J. J. (2013). A coastal seawater temperature dataset for biogeographical studies: large biases between in situ and remotely-sensed data sets around the coast of South Africa. PLOS One, 8(12), e81944. https://doi. org/10.1371/journal.pone.0081944

Southern, R. (1914). Clare Island Survey. Archiannelida and Polychaeta. Proceedings of the Royal Irish Academy, 31(47), 1-160.

Tewary, S. A. (2015). Taxonomy of the Bitentaculate Cirratulidae (Polychaeta) (Master's thesis), Boston, USA: University of Massachusetts Boston.

Weidhase, M., Bleidorn, C., \& Simon, C. A. (2016). On the taxonomy and phylogeny of Ctenodrilus (Annelida: Cirratulidae) with a first report from South Africa. Marine Biodiversity, 46, 243-252. 